\title{
Resistance of Saccharine Sorghum Cultivars to Sugarcane Borer Diatraea saccharalis
}

\author{
Lauren Medina Barcelos ${ }^{1}$, Ana Paula Afonso Rosa ${ }^{2}$, Beatriz Marti Emygdio ${ }^{2}$, Ricardo Alexandre Valgas ${ }^{2}$ \\ \& Indyra Carvalho Faria ${ }^{3}$ \\ ${ }^{1}$ Centro Universitário Univates, Brazil \\ ${ }^{2}$ Embrapa Clima Temperado, Brazil \\ ${ }^{3}$ Universidade Federal de Pelotas, Brazil \\ Correspondence: Ana Paula Afonso Rosa, Embrapa Clima Temperado, Brazil. E-mail: ana.afonso@embrapa.br
}

Received: June 3, 2018

Accepted: July 2, $2018 \quad$ Online Published: August 15, 2018

doi:10.5539/jas.v10n9p364

URL: https://doi.org/10.5539/jas.v10n9p364

\begin{abstract}
The saccharine sorghum has been investigated as a complementary source of raw material for ethanol production, especially during the sugarcane off-season, however, it has been susceptible to the attack of the sugarcane borer Diatraea saccharalis. The objective of this work was to verify the effect of sorghum cultivars on D. saccharalis' biological parameters. Cultivars, BRS 506, BRS 509 and BRS 511 were used to determine duration and survival rates of eggs, larvae, pre-pupae and pupa phases, along with larval weight and adult longevity. $D$. saccharalis completed its biological cycle in all treatments, however, when fed with dry extracts of BRS 509 cultivar, the net reproduction rate, the intrinsic rate of increase and the finite rate of increase was superior from the others. BRS 506 was the cultivar that negatively affected $D$. saccharalis' biological parameters, with possible antibiosis effect. Based on this study, the sorghum cultivars evaluated are not recommended for a grain production system, since D. saccharalis' larvae presented good development when fed with its dry extract incorporated into the diet.
\end{abstract}

Keywords: Diatraea saccharalis, development, cultivars

\section{Introduction}

The current scenario of Brazilian bioenergy production, from a sustainable perspective, necessarily involves the diversification of raw materials (Barcelos et al., 2016). Thus, one of the most promising alternatives of renewable sources for ethanol production is the saccharine sorghum [Sorghum bicolor (L.) Moench] mainly because it has a high content of soluble carbohydrates and increased stem yield, very similar to sugarcane. The saccharine sorghum can be cultivated in regions where sugarcane is not well adapted, planted in rotation with other annual crops and it can potentially be sown in non-cultivated areas (Emygdio, 2010).

The sugarcane borer, Diatraea saccharalis (Fabricius, 1794) (Lepidoptera: Crambidae), is a major pest of sugarcane, corn, rice and sorghum crops. After hatching, early-instar larvae scrape the leaf limb migrating internally to the base of the sheath, in which they penetrate the stem, and as it feeds on the parenchyma, it starts to form galleries in the plant, causing direct damages due to the consumption of plant tissues, and indirect damages, related to the further entry of opportunistic microorganisms. These damages in some regions of Brazil, can correspond to 30\% of the total grain production (Mendes et al., 2012, 2014).

Once larvae penetrate the stem, its control becomes difficult, not only because of the insect's behavioural characteristics, but also, because of the low availability of insecticides registered for sorghum crops (Agrofit, 2018). Hence, host-plant resistance to $D$. saccharalis emerges as an economically and environmentally effective control measure, mostly because it reduces costs related to pest control and therefore is one of the key factors for sorghum to be established as an alternative to sugarcane in the ethanol industry.

Previous studies have shown that sorghum cultivars have varied levels of resistance to $D$. saccharalis, therefore, there is a need to detect which genotypes are resistant and a need to clarify what type of resistance is involved (Boiça Jr. et al., 1997; Cruz, 2016).

Given the above, this study aimed to investigate the effect of three saccharine sorghum cultivars on biological parameters of $D$. saccharalis. 


\section{Materials and Methods}

The experiments were conducted at the Bioefficiency Centre of Embrapa Clima Temperado- Low Lands Experimental Station, located in the county of Capão do Leão/RS. For the study of Diatraea saccharalis' biological parameters, an artificial diet was incorporated with dry extracts of saccharine sorghum cultivars BRS 506, BRS 509 and BRS 511, these cultivars were chosen mainly because of their importance and wide use in the south of Brazil (Reunião Técnica Anual do Milho $62^{\mathrm{a}} \&$ Reunião Técnica do Sorgo 45 ${ }^{\mathrm{a}}$, 2017).

The artificial diet described by Hensley and Hammond (1968) was used (Table 1) and we then added shredded leaves and stems according to Bortoli et al. (1989).

Table 1. Composition of artificial diet to Diatraea saccharalis according to Hensley and Hammond (1968)

\begin{tabular}{ll}
\hline Ingredients & Amount \\
\hline Wheat germ (Walmon Lot: 18112014) & $15.0 \mathrm{~g}$ \\
Soy protein (Walmon Lot: 13102014) & $54.0 \mathrm{~g}$ \\
Sugar & $52.5 \mathrm{~g}$ \\
Salts of Wesson (Walmon) & $7.5 \mathrm{~g}$ \\
Ascorbic acid (Synth) & $1.9 \mathrm{~g}$ \\
Pure iron chloride (Walmon Lot: 232) & $0.4 \mathrm{~g}$ \\
Vita Gold (Tortuga) & $0.4 \mathrm{~g}$ \\
Nipagin (Antarctic) & $3.0 \mathrm{~g}$ \\
Tetracycline (Med.) & $0.13 \mathrm{~g}$ \\
Vitamin solution (Rezenflex) & $11.3 \mathrm{ml}$ \\
Formaldehyde (Synth) & $0.75 \mathrm{ml}$ \\
Agar (Dynamic) & $11.3 \mathrm{~g}$ \\
Water & $900.0 \mathrm{ml}$ \\
\hline
\end{tabular}

Flat-bottom glass tubes $(8.5 \mathrm{~cm} \times 2.5 \mathrm{~cm})$ were filled with $1 / 3$ of the diet above according to the methodology proposed by Parra (1999). The controls consisted on glass tubes containing diet without dry extracts. In each of the control tubes, one first instar larva was inoculated (total of 130 tubes). In the other treatments, two first instar larvae were inoculated (totalizing 200 tubes). All tubes were closed with hydrophobic cotton and kept under controlled laboratory conditions $\left(25 \pm 2{ }^{\circ} \mathrm{C}, 70 \pm 10 \% \mathrm{RH}\right.$, and a photoperiod of $14 \mathrm{~h} 10$ [L:D]) (De Conti, 2012).

Subsequently, daily assessments of the following biological variables were made: larval phase (duration and viability), pre-pupal (duration and viability), pupal (duration, $24 \mathrm{~h}$ old weight (g), viability, sex ratio and deformations) and adults (pre-oviposition and oviposition duration, fecundity and longevity). To determine the number of instars, the cephalic capsule width was measured in groups of 10 larvae, using a stereoscopic microscope connected to a micrometer eyepiece.

The experiments were conducted in a completely randomized design. The data was submitted to variance analysis (ANOVA), and the mean values obtained by ANOVA were compared using Tukey's test $(p \leq 0.05)$ and the pupal weight using Kruskal Wallis' test, both through the statistical software Genes (Cruz, 2010). Time-related variables were analysed through Survival Analysis, a statistical method commonly used to evaluate survival data in laboratory studies (Lee, 1992). The fertility life table described by Silveira Neto (1976) was plotted using the following data: duration of the development period (egg-adult), total viability, sex ratio, pre-oviposition period, number of eggs per day and daily mortality of females and males. From the biological data obtained, we estimated the average duration of one generation (T), the net reproduction rate (Ro), the intrinsic rate of increase $(\mathrm{rm})$ and the finite rate of increase $(\lambda)$.

\section{Results and Discussion}

The mean duration of the larval stage was 26 days on the three sorghum cultivars and 34.6 days on the control, which differed significantly from the other treatments (Table 2). The results showed that cultivars extracts, when incorporated into the diet affected $D$. saccharalis' larval growth when compared to the control whose phase was longer (Melo \& Parra, 1988). The reduction in the larval phase may indicate that the dry extract favoured the insect's development (Nava \& Parra, 2005). On the other hand, it can also indicate non-preference or an antixenosis effect, which is characterized by lower food consumption, resulting in insects with low viability (Vendramim \& Guzzo, 2009). 
Table 2. Duration and viability of Diatraea saccharalis larval phase in artificial diet containing sorghum dry extract in laboratory conditions, Pelotas-RS

\begin{tabular}{lll}
\hline Cultivars & Larval period (days) & Viability $(\%)$ \\
\hline BRS 506 & $24.5 \pm 0.25 \mathrm{c}^{1}$ & $21.5 \pm 12.46 \mathrm{~b}^{2}$ \\
BRS 509 & $26.1 \pm 0.36 \mathrm{~b}$ & $25.7 \pm 11.39 \mathrm{~b}$ \\
BRS 511 & $25.1 \pm 0.30 \mathrm{bc}$ & $59,0 \pm 7.52 \mathrm{a}$ \\
Control & $34.6 \pm 1.34 \mathrm{a}$ & $69.0 \pm 4.01 \mathrm{a}$ \\
\hline CV\% & 25.0 & 25.7 \\
\hline
\end{tabular}

Note. ${ }^{1}$ Means values in a column followed by different lowercase letters are significantly different on the basis of ANOVA with Tukey Test $(P<0.05) ;^{2}$ Data transformed to $\sqrt{x+0.5}$.

According to the survival analysis, it is estimated that larvae feeding on BRS 506 and BRS 509 cultivars could have longer phases, up to 40 days (Figure 1).

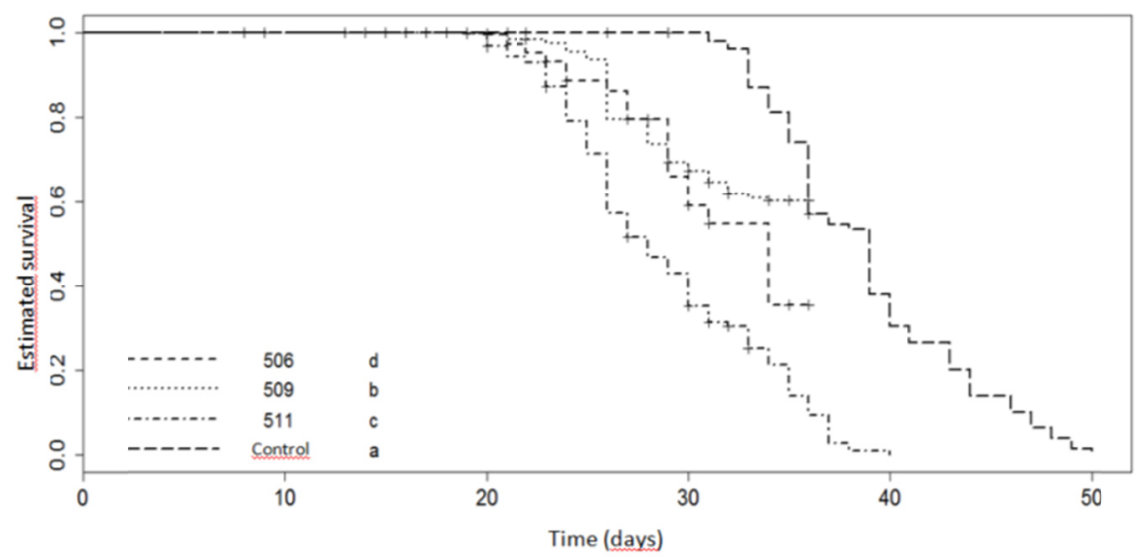

Figure 1. Estimated survival rate of Diatraea saccharalis larvae in artificial diet containing sorghum dry extracts, Pelotas-RS

Along with the cultivar factor, nitrogen fertilization on sorghum crops can interfere on the sugarcane borer's biology, mainly because it can prolongate the larval period over 72 days. As the nitrogen dose reduce, the larval period increase, showing that this nutrient plays an especial role in the insect's development (Bortoli et al., 2005).

Insects feeding on the control treatment and on BRS 511 cultivar, had greater viability rates and significant statistical difference from the other treatments (Table 2). Whereas all treatments were kept under the same controlled conditions, this result may indicate that BRS 506 and BRS 509 are not suitable for D. saccharalis' development, indicating that they can cause an adverse effect on the insect's biology or non-feeding preference for these cultivars. This was also observed in studies testing sugarcane varieties, in which they demonstrated the influence of the diet on the development of the sugarcane borer, with significant differences on the larval phase duration, due to feeding (Boiça Jr. et al., 1997). The numbers of instars by the graphic model, indicated that $D$. saccharalis had three instars in all treatments (Figure 2). Even though the growth rate obtained in each treatment were found within the established interval (Dyar, 1890) it is unusual for this species to go through 3 instars, and since this result also occurred for insects that weren't influenced by sorghum extracts, we can infer that the reduction of instars can be due to other factors other than food. 

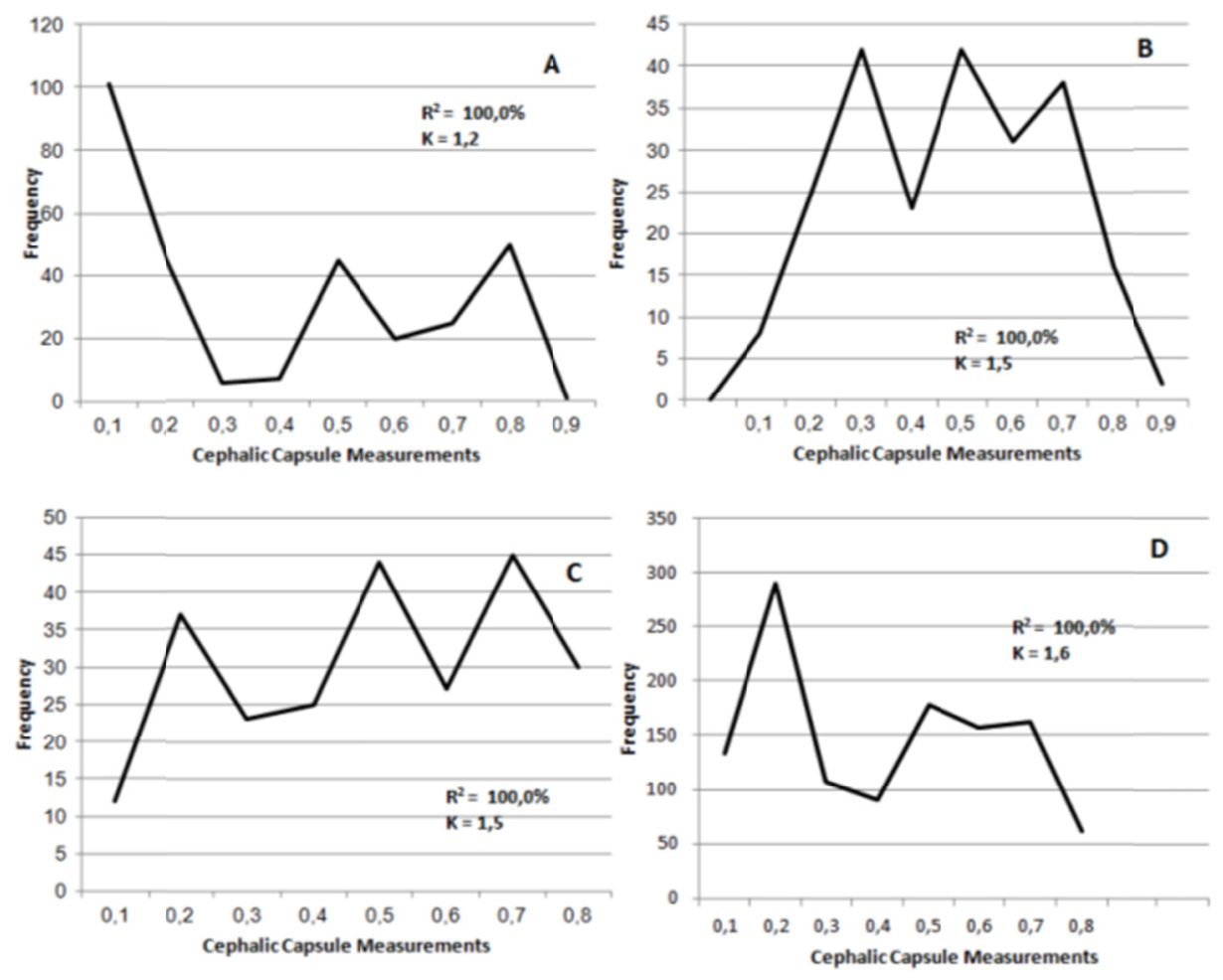

Figure 2. Distribution of Diatraea saccharalis' cephalic capsule measurements in (A) artificial diet+ BRS 506, (B) artificial diet + BRS 509, (C) artificial diet+ BRS 511, (D) artificial diet without sorghum extracts, Pelotas-RS

The duration of the pre-pupal phase was on average, one day, but through the estimated survival analyses (Figure 3 ), we observed that this period could extend for up to 3 more days for insects feeding on the BRS 506 cultivar. For all treatments, viability was of $100 \%$, with no significant difference among treatments, evidencing that there was no influence of the diet in this parameter (Table 3).

Table 3. Duration and viability of Diatraea saccharalis pre-pupal and pupal phase in artificial diet containing dry sorghum extracts, in laboratory, Pelota-RS

\begin{tabular}{|c|c|c|c|c|}
\hline \multirow{2}{*}{ Cultivar } & \multicolumn{2}{|c|}{ Pre-pupa } & \multicolumn{2}{|c|}{ Pupa } \\
\hline & Duration (days) & Viability (\%) & Duration (days) & Viability (\%) \\
\hline BRS 506 & $1.0 \pm 0.19 b^{1}$ & $100.0 \pm 2.69 a$ & $6.8 \pm 0.2 \mathrm{~d}^{1}$ & $65.1 \pm 3.33 \mathrm{c}^{2}$ \\
\hline BRS 509 & $1.1 \pm 0.03 \mathrm{a}$ & $100.0 \pm 2.94 \mathrm{a}$ & $8.2 \pm 0.3 \mathrm{c}$ & $76.6 \pm 3.36 b c$ \\
\hline BRS 511 & $1.0 \pm 0.004 b$ & $100.0 \pm 4.44 \mathrm{a}$ & $9.0 \pm 1.4 b$ & $91.5 \pm 4.64 \mathrm{a}$ \\
\hline Control & $1.2 \pm 0.04 \mathrm{a}$ & $100.0 \pm 1.53 \mathrm{a}$ & $9.7 \pm 0.03 \mathrm{a}$ & $89.7 \pm 2.87 \mathrm{ab}$ \\
\hline $\mathrm{CV} \%$ & 25.2 & 42.3 & 26.9 & 42.4 \\
\hline
\end{tabular}

Note. ${ }^{1}$ Means values in a column followed by different lowercase letters are significantly different on the basis of ANOVA with Tukey Test $(P<0.05) ;{ }^{2}$ Data transformed to $\sqrt{x+0.5}$. 


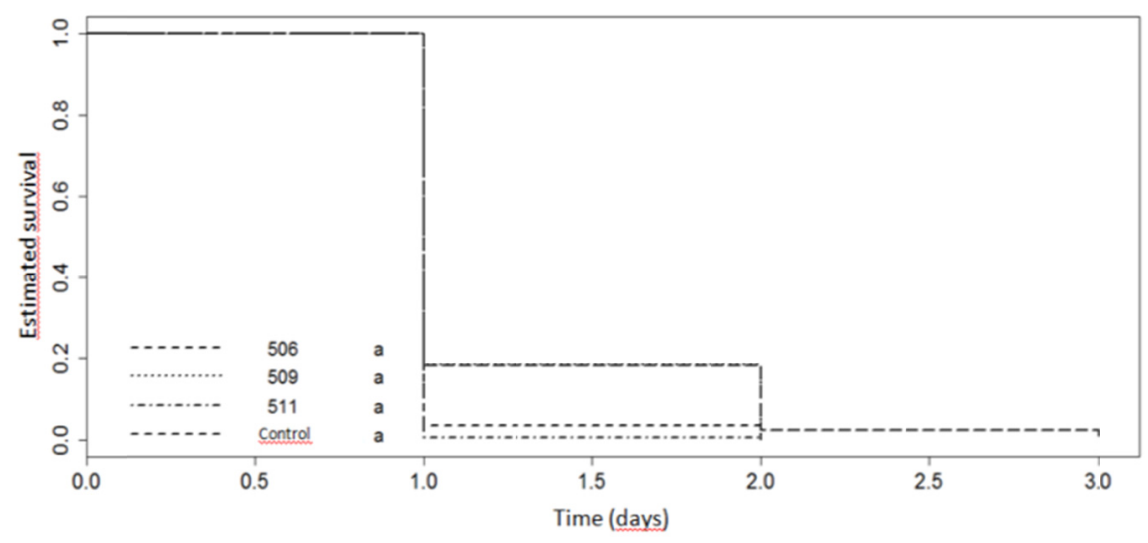

Figure 3. Estimated survival of Diatraea saccharalis pre-pupal and pupal period of larvae fed on artificial diet containing sorghum dry extracts, Pelotas-RS

In the pupal stage, there was significant difference among treatments, with a mean variation of 6.8 to 9.0 days between sorghum cultivars and 9.7 days in the control (Table 3). According to the literature, the influence of different genotypes of maize and sorghum on $D$. saccharalis' development provided an average pupal period of 4 to 6 days. The same happened in studies assessing the effect of artificial diets with variable concentrations of sugarcane stems, which showed that diets containing $25 \%$ of crushed stems increased de pupal period (9.2 days) while artificial diet with $100 \%$ of stems had means significantly lower (8.0 days) (Bortoli et al., 2005; Boiça Jr. et al., 2011), indicating that the quality of the diet in the larval phase can be a conditioning factor in the insect's biology and vigor. In the present study, insects with longer durations of the pupal period were fed on BRS 511, which also presented higher viability.

The highest estimate of pupal survival was 25 days for insects from the artificial diet without incorporation of sorghum, probably because there was no effect of the cultivars (antibiosis), and the lowest survival rate was for BRS 508 (Figure 4).

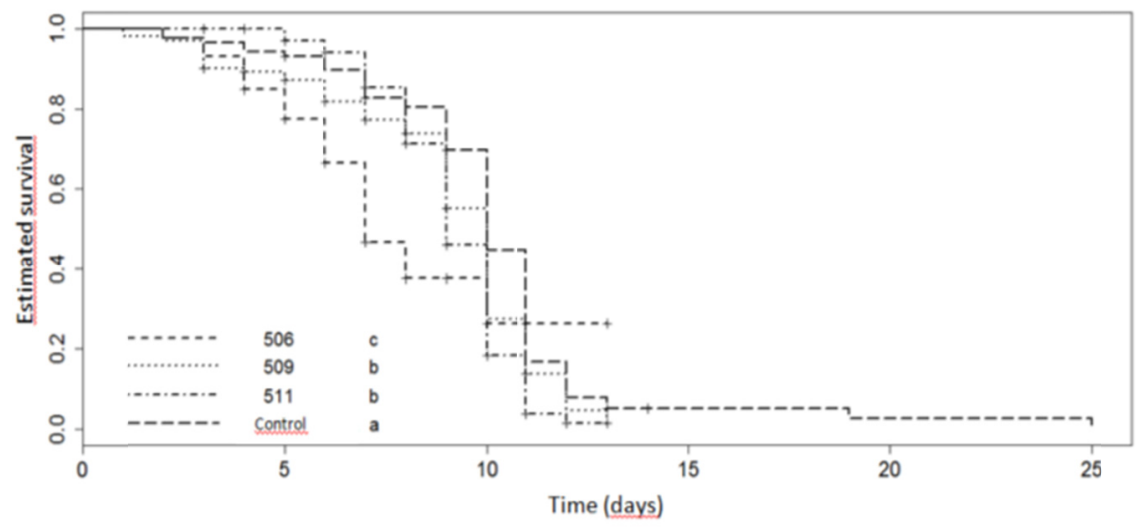

Figure 4. Estimated survival rate of Diatraea saccharalis larvae in artificial diet containing sorghum dry extracts, Pelotas-RS

We observed that in the larval phase, insects fed on artificial diet without sorghum had heavier pupae (Table 4), in other words, the quality of the diet affected de pupal weight, indicating that the insect's feeding preferences or antibiosis resistance can be related to the addition of dry extracts in the artificial diet (Santos et al., 2005). 
Table 4. Pupae weight (mg) of Diatraea saccharalis in sorghum cultivars, Pelotas-RS

\begin{tabular}{llll}
\hline Cultivar & Observed Difference & Critical Difference & Difference \\
\hline BRS 506-BRS 509 & $75.37^{1}$ & 57.12 & Yes \\
BRS 506-BRS 511 & 29.36 & 49.25 & No \\
BRS 506-Test & 190.97 & 59.29 & Yes \\
BRS 509-BRS 511 & 46.01 & 46.18 & No \\
BRS 509-Test & 266.35 & 56.77 & Yes \\
BRS 511-Test & 220.33 & 48.84 & Yes \\
\hline
\end{tabular}

Note. ${ }^{1}$ Means compared by the Kruskal Wallis test.

The quality of the diet also influenced adults' longevity, the average duration of this phase ranged from 3.1 to 5.1 days, with the shortest duration on BRS 506 cultivar and the longest duration on BRS 509 and BRS 511 cultivars (Table 4), however, according to the survival analysis, the estimated life of an adult is superior then 6 days in all treatments (Figure 5). These results are similar to those found by Bortoli et al. (1989), on which adults' longevity varied from 3 to 4 days. In this study, the pre-oviposition period lasted on average 2 days in all treatments, similarly to the ones found by Melo and Parra (1988). The cultivars also affected the sex ratio (Table 5), with a higher value observed in adults fed on BRS 511 cultivar, these means are similar to the ones found in studies with D. saccharalis kept on artificial diet (0.43) (Costa et al., 2010). Experiments conducted in maize, showed that larvae when fed on cultivars with a high starch content, had a large proportion of females $(\mathrm{SR}=0.77)$, probably due to differences in amino acids concentrations (Zárate et al., 2007).

Table 5. Adult longevity and sex ratio of Diatraea saccharalis in artificial diet with sorghum dry extract in laboratory, Pelotas-RS

\begin{tabular}{lll}
\hline Cultivar & Duration (days) & Sex Ratio (\%) \\
\hline BRS 506 & $3.1 \pm 0.25 \mathrm{c}^{1}$ & $0.30 \mathrm{~b}^{2}$ \\
BRS 509 & $5.1 \pm 0.58 \mathrm{a}$ & $0.31 \mathrm{~b}$ \\
BRS 511 & $4.7 \pm 0.11 \mathrm{ab}$ & $0.49 \mathrm{a}$ \\
Control & $4.2 \pm 0.19 \mathrm{~b}$ & $0.46 \mathrm{ab}$ \\
CV\% & 38.3 & 25.4 \\
\hline
\end{tabular}

Note. ${ }^{1}$ Means values in a column followed by different lowercase letters are significantly different on the basis of ANOVA with Tukey Test $(P<0.05) ;^{2}$ Data transformed to $\sqrt{x+0.5}$.

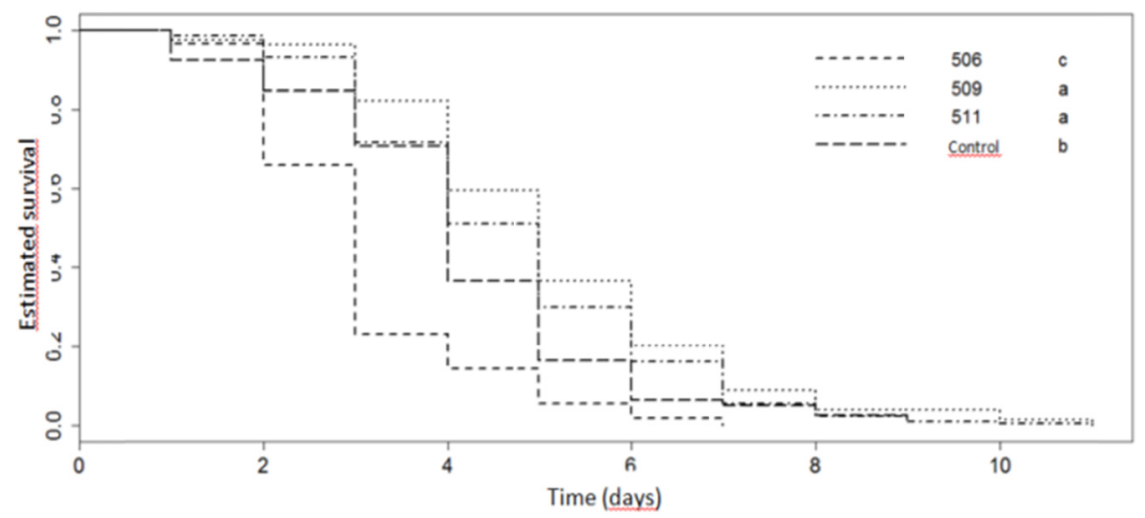

Figure 5. Estimated survival of Diatraea saccharalis adults in artificial diet with sorghum in laboratory, Pelotas-RS

The average incubation period of $D$. saccharalis' eggs was five days for the three cultivars and seven days for the control, differing significantly between BRS 509 and BRS 511 (Table 6). These results are similar to those found by Linares (1987), in which was verified that D. saccharalis' egg period was of 6.29 days. 
Table 6. Duration and viability of Diatraea saccharalis' egg phase in artificial diet and sorghum in laboratory, Pelotas-RS

\begin{tabular}{lll}
\hline Cultivar & Duration (days) & Viability (\%) \\
\hline BRS 506 & $5.7 \pm 0.25 \mathrm{ab}^{1}$ & $47.5 \pm 5.31 \mathrm{~b}$ \\
BRS 509 & $4.5 \pm 0.53 \mathrm{~b}$ & $52.8 \pm 8.14 \mathrm{~b}$ \\
BRS 511 & $5.0 \pm 0.20 \mathrm{~b}$ & $72.0 \pm 8.34 \mathrm{a}$ \\
Control & $7.0 \pm 0.51 \mathrm{a}$ & $58.3 \pm 9.26 \mathrm{~b}$ \\
CV\% & 16.8 & 79.3 \\
\hline
\end{tabular}

Note. ${ }^{1}$ Means values in a column followed by different lowercase letters are significantly different on the basis of ANOVA with Tukey Test $(P<0.05)$.

Egg's viability ranged from 47.5 to $72.0 \%$ (Table 6), similar values are also obtained in natural conditions $(67.5 \%)$ (Guevara \& Windl, 1980), however this viability can be considered low since sugarcane is $D$. saccharalis' preferential host. Although this species is polyphagous, out of the 17 Gramineae evaluated in Porto Rico, the oviposition preference was on maize, sugarcane and sorghum, and the same with the most attractive and acceptable species for first instar larvae (Quintana-Muniz \& Walker, 1970).

The average duration of each generation $(\mathrm{T})$ was higher for the control and when sorghum dry extracts were added, it was higher on BRS 511 cultivar. The net reproductive rate (Ro) was 2.98 when larvae were fed in artificial diet + BRS 511, 8.54 for artificial diet + BRS 509, 1.20 for artificial diet + BRS 506 and 4.82 for artificial diet without sorghum extracts, showing that the ability to generate female offspring per females at the end of the generation (Ro) was higher for insects fed on BRS 509. The intrinsic rate of increase (rm) was positive, evidencing a population increase, especially higher when fed with BRS 509 cultivar $(0.050)$, the same happened to the finite rate of increase $(\lambda)$ on which BRS 509 had 1.051 females/day. Similar values of T and $\lambda$ were found by Lima (2011), however the rm and Ro were higher (Table 7). These values indicate that, although the cultivars are not D. saccharalis' preferential hosts, they may cause an increase in the insect's population.

Table 7. Average duration of one generation (T), net reproductive rate (Ro), the intrinsic rate of increase (rm) and finite rate of increase $(\lambda)$ of Diatraea saccharalis, fed in artificial diet + sorghum extracts, Pelotas-RS

\begin{tabular}{lllll}
\hline Cultivar & T (days) & Ro & $\mathrm{r}_{\mathrm{m}}$ & $\lambda$ \\
\hline BRS 506 & 41.5 & 1.20 & 0.004 & 1.004 \\
BRS 509 & 42.9 & 8.54 & 0.050 & 1.051 \\
BRS 511 & 44.0 & 2.98 & 0.025 & 1.025 \\
Control & 59.0 & 4.82 & 0.027 & 1.027 \\
\hline
\end{tabular}

Sorghum dry extracts when incorporated to artificial diet, enabled D. saccharalis' development, however more studies are needed, especially testing natural diets. Based on this study, it's not recommended to use these cultivars when there is a history of $D$. saccharalis occurrence, mostly becauseeven though they interfered in the biological parameters, the insects completed their development in all cultivars.

\section{Conclusions}

The tested saccharine sorghum cultivars when incorporated to artificial diet, prove to be adequate for $D$. saccharalis'development.

BRS 511 cultivar provides higher viability to all phases of $D$. saccharalis' development.

BRS 506 cultivar has an antibiosis effect on D. saccharalis.

\section{References}

Agrofit. (2018). Ministério da Agricultura, Pecuária e Abastecimento. Retrieved April 13, 2018, from http://www.agricultura.gov.br/servicos-e-sistemas/sistemas/agrofit

Barcelos, C. A., Maeda, R. N., Santa Anna, L. M. M., \& Pereira, N. (2016). Sweet sorghum as a whole-crop feedstock for ethanol production. Biomass \& Bioenergy, 94, 46-56. https://doi.org/10.1016/j.biombioe. 2016.08.012 
Boiça Jr., A. L., Lara, F. M., \& Bellodi, M. P. (1997). Influência de variedades de cana-de-açúcar, incorporadas em dieta artificial, no desenvolvimento de Diatraea saccharalis (Fabr.) e no seu parasitismo por Cotesia flavipes (Cam.). Anais da Sociedade Entomológica do Brasil, 26(3), 537-542. https://doi.org/10.1590/ S0301-80591997000300017

Boiça Jr., A. L., Leonelo, A. F., \& Jesus, A. F. (2011). Dietas artificiais incorporadas ou não a colmos triturados de variedades de cana-de-açúcar na biologia de Diatraea saccharalis (F.) (Lepidoptera: Crambidae). Ciências Agrárias, 32(1), 39-48. https://doi.org/10.5433/1679-0359.2011v32n1p39

Bortoli, A. S., Dória, H. O. S., Albergaria, N. M. M. S., \& Botti, M. V. (2005). Aspectos biológicos e dano de Diatraea saccharalis (Fabr., 1794) (Lepidoptera: Pyralidae) em sorgo cultivado sob diferentes doses de nitrogênio e potássio. Ciência e Agrotecnologia, 29(2), 267-273. https://doi.org/10.1590/S1413-7054200 5000200001

Bortoli, S. A., Boiça Júnior, A. L., Cunha, H. F., Lendell, M. G. A., \& Matos, P. P. (1989). Influência de diferentes genótipos de sorgo e milho na biologia de Diatraea saccharalis (Fabricius, 1794) (Lepidoptera: Pyralidade), criada em dieta artificial. Ecossistema, 14, 204-212. https://doi.org/10.1590/S0301-80591997 000300017

Costa, D. M., Coelho, A. C., \& Rigolin-Sá, O. (2010). Biologia da broca da cana-de-açúcar (Diatraea saccharalis) (Lepidoptera: Crambidae) em dieta artificial. Ciência et Praxis, 3(5), 13-16.

Cruz, C. D. (2010). Programa Genes-Aplicativo computacional em genética e estatística. Retrieved from https://www.ufv.br/dbg/genes/genes.htm

Cruz, S. C. B. (2016). Avaliação da infestação de Diatraea saccharalis em diferentes genótipos de sorgo sob diferentes doses de nitrogênio e potássio (Trabalho de Conclusão de Curso, Universidade Federal de São João Del Rei, Sete Lagoas).

De Conti, B. F. (2012). Exigências térmicas e monitoramento de Diatraea saccharalis (Fabricius, 1974) (Lepidoptera: Crambidae), como suporte ao seu controle biológico (Tese., Universidade de São Paulo, Escola Superior de Agricultura “Luiz de Queiroz”, São Paulo).

Dyar, H. G. (1980). The number of molts of lepidopterous larvae. Psyche, 5, 420-422. https://doi.org/10.1155/ $1890 / 23871$

Emygdio, B. M. (2010). Produção de etanol a partir de sorgo sacarino. Artigo em Hypertexto. Retrieved from http://www.infobibos.com/Artigos/2010_4/sorgo/index.htm

Guevara, L. A. C., \& Wiendl, F. M. (1980). Aspectos da biologia, em condições de campo, da broca da cana-de-açúcar, Diatraea saccharalis (Fabricius, 1794). Revista Agropecuária Técnica, 1(1), 32-39. https://doi.org/10.25066/agrotec.v1i1

Henseley, S, D., \&Hammond, A. M. (1968). Laboratory techniques for rearing the sugar cane borer on an artificial diet. Journal of Economic Entomology, 61(6), 1742-1743. https://doi.org/10.1093/jee/61.6.1742

Lee, E. T. (1992). Statistical Methods for Survival Data Analysis. John Wiley \& Sons.

Lima, A. A. (2011). Comparação de dietas artificiais para criação de Diatraea saccharalis (Lepidoptera: Crambidae) e avaliação da qualidade de Cotesia flavipes (Hymenoptera: Braconidae) em criações massais (Dissertação, Instituto Biológico, da Agência Paulista de Tecnologia dos Agronegócios, São Paulo).

Linares, B. A. F. (1987). Influencia de la temperatura en el desarrollo de Diatraea saccharalis. Caña de Azúcar, $5(2), 43-66$.

Melo, A. B. P., \& Parra, J. R. P. (1988). Biologia de Diatraea saccharalis em diferentes temperaturas. Pesquisa Agropecuária Brasileira, 23(7), 663-680.

Mendes, S. M., Viana, P. A., Cruz, I., \& Waquil, J. M. (2012). Controle de Pragas. In A. May, F. O. M. Durães, I. A. Pereira Filho, R. E. Schaffert, \& R. A. da C. Parrella (Eds.), Sistema Embrapa de produção de sorgo para bioetanol: Sistema BRS1G-Tecnologia Qualidade Embrapa. Sete Lagoas: Embrapa Milho e Sorgo.

Mendes, S. M.,Waquil, J. M., Rodrigues, J. A. S., Sampaio, M. V., \& Viana, P. A. (2014). Manejo de pragas na cultura do sorgo. Informe Agropecuário, 35(278), 89-99.

Nava, D. E., \& Parra, J. R. P. (2005). Biologia de Stenoma cantenifer Walsingham (Lepidoptera: Elachistidae) em dieta natural e artificial e estabelecimento de um sistema de criação. Neotropical Entomology, 34, 751-75. https://doi.org/10.1590/S1519-566X2005000500006 
Parra, J. R. P. (1999). Técnicas de criação de insetos para programas de controle biológico. Piracicaba: FEALQ.

Quintana-Muñiz, V., \& Walker, D. W. (1970). Oviposition preference by gravid sugarcane borer moths in Puerto Rico. Journal of Economic Entomology, 63, 987-988. https://doi.org/10.1590/1413-70542017414004317

Reunião Técnica Anual do Milho 62 ${ }^{\mathrm{a}}$, \& Reunião Técnica do Sorgo 45a . (2017). Indicações técnicas para o cultivo de Milho e de Sorgo no Rio Grande do Sul, Safras: 2016/2017, 2017/2018. Brasília, DF: Embrapa.

Santos, K. B., Meneguim, A. M., \& Neves, P. M. O. J. (2005). Biologia de Spodoptera eridania (Cramer) (Lepidoptera: Noctuidae) em diferentes hospedeiros. Neotropical Entomology, 34, 903-910. https://doi.org/ $10.1590 / \mathrm{S} 1519-566 \mathrm{X} 2005000600005$

Silveira Neto, S., Nakano, O., Barbin, D., \& Vila Nova, N. A. (1976). Manual de ecologia de insetos. São Paulo: Ceres.

Vendramim, J. D., \& Guzzo, E. C. (2009). Resistência de plantas e a bioecologia e nutrição dos insetos. In A. R. Panizzi, \& J. R. P. Parra (Eds.), Bioecologia e nutrição dos insetos: base para o manejo integrado de pragas. Brasília: Embrapa Informação Tecnológica.

Zárate, L. L., Rodríguez, L. V., Espinoza, R. R., \& Vergaray, H. E. (2007). Biología de Diatraea saccharalis Fabr. (Lepidoptera: Pyralidae) alimentado con dos tipos de Zea mays (L.). Pueblo Continente, 18(1), 85-93.

\section{Copyrights}

Copyright for this article is retained by the author (s), with first publication rights granted to the journal.

This is an open-access article distributed under the terms and conditions of the Creative Commons Attribution license (http://creativecommons.org/licenses/by/4.0/). 